\title{
Optymalizacja warunków oznaczania wody metodą miareczkowania kulometrycznego z odparowaniem dla olejów smarowych
}

\author{
Optimization of the water determination conditions by coulometric titration with \\ evaporation for lubricating oils
}

\author{
Sylwia Jędrychowska \\ Instytut Nafty i Gazu - Państwowy Instytut Badawczy
}

\begin{abstract}
STRESZCZENIE: Wiedza o zawartości wody w produktach naftowych, między innymi olejach smarowych, dodatkach oraz różnych innowacyjnych produktach, jest istotna z punktu widzenia ich wytwarzania, zakupu czy sprzedaży ze względu na wpływ na ich jakość i charakterystykę działania. W przypadku olejów smarowych obecność wody może stanowić przyczynę przedwczesnej korozji i zużycia, powstawania osadów, co prowadzi do ograniczenia smarowania i przedwczesnego zatkania filtrów, osłabienia działania dodatków czy niepożądanego wzrostu bakterii. W artykule przedstawiono prace nad dobraniem optymalnych warunków oznaczania zawartości wody metodą miareczkowania kulometrycznego Karla Fischera z odparowaniem w olejach smarowych. Badania przeprowadzono z wykorzystaniem kulometru z celą miareczkową bez diafragmy firmy Metrohm model 917 Coulometer wraz automatycznym podajnikiem próbek wyposażonym w komorę grzejną 885 Compact Oven Sample Changer. Do badań wytypowano różne rodzaje olejów smarowych, a mianowicie oleje silnikowe o różnej klasie lepkości (5W-40, 10W-40, 15W-40, 5W-30), olej przekładniowy, olej hydrauliczny, olej turbinowy, olej bazowy oraz płyn hydrauliczny. Wszystkie wytypowane próbki olejów smarowych badano w czterech różnych warunkach pomiarowych: $110^{\circ} \mathrm{C}$ i $20 \mathrm{ml} / \mathrm{min} ; 150^{\circ} \mathrm{C}$ i $50 \mathrm{ml} / \mathrm{min}, 180^{\circ} \mathrm{C}$ i $50 \mathrm{ml} / \mathrm{min}$ oraz $150^{\circ} \mathrm{C} \mathrm{i} 70 \mathrm{ml} / \mathrm{min}$. Stwierdzono, że w przypadku wszystkich wyżej wymienionych olejów smarowych najlepsze wyniki uzyskano przy ustawieniu temperatury pieca na $150^{\circ} \mathrm{C}$ i przy przepływie gazu nośnego wynoszącym $50 \mathrm{ml} / \mathrm{min}$ lub $70 \mathrm{ml} / \mathrm{min}$. Określono wpływ różnych czynników, takich jak naważka próbki, temperatura pieca, prędkość przepływu gazu nośnego, na przebieg badania oraz szybkość analizy. Zwiększony przepływ gazu nośnego do $70 \mathrm{ml} / \mathrm{min}$ nie powoduje skrócenia czasu analizy. W niektórych przypadkach wzrost temperatury pieca może przyspieszyć szybkość analizy, ale jest to dość ryzykowne dla niektórych próbek, które w tej temperaturze ulegają rozkładowi. W związku z tym bezpieczniej jest prowadzić badanie w temperaturze pieca $150^{\circ} \mathrm{C}$. Największy wpływ na szybkość analizy ma odpowiedni dobór naważki próbki poddanej analizie. W zależności od zawartości wody w badanej próbce należy dobrać odpowiednią naważkę próbki. Powinna być ona na tyle mała, aby nadmiernie nie wydłużać analizy, ale także na tyle duża, żeby ilość odmiareczkowanej wody była przynajmniej dwukrotnie większa niż w ślepej próbie.
\end{abstract}

Słowa kluczowe: woda, miareczkowanie kulometryczne KF z odparowaniem, oleje smarowe.

\begin{abstract}
The knowledge of the water content of various petroleum products, including lubricating oils, additives and various innovative products, is important from the point of view of manufacturing, purchasing or selling them, due to the impact on their quality and performance characteristics. In the case of lubricating oils, the presence of water can lead to premature corrosion and wear, the formation of deposits, which leads to reduced lubrication and premature clogging of filters, reduced action of additives or undesirable bacterial growth. The article presents the study on the selection of optimal conditions for the determination of water content by coulometric Karl-Fischer titration with evaporation in lubricating oils. The tests were carried out using a coulometer with a titration cell without a diaphragm by Metrohm, 917 Coulometer model with an automatic sample feeder equipped with a heating chamber 885 Compact Oven Sample Changer. Various types of lubricating oils were selected for testing, namely engine oils of different viscosity classes $(5 \mathrm{~W} / 40,10 \mathrm{~W} / 40,15 \mathrm{~W} / 40,5 \mathrm{~W} / 30)$, gear oil, hydraulic oil, turbine oil, base oil and hydraulic fluid. All selected samples of lubricating oils were tested in four different measuring conditions: $110^{\circ} \mathrm{C}$ and $20 \mathrm{ml} / \mathrm{min} ; 150^{\circ} \mathrm{C}$ and $50 \mathrm{ml} / \mathrm{min}, 180^{\circ} \mathrm{C} \mathrm{and} 50 \mathrm{ml} / \mathrm{min}$ and $150^{\circ} \mathrm{C}$ and $70 \mathrm{ml} / \mathrm{min}$. It was found that for all the lubricating oils, the best results were obtained with a furnace temperature setting of $150^{\circ} \mathrm{C}$ and a carrier gas flow of $50 \mathrm{ml} / \mathrm{min}$ or $70 \mathrm{ml} / \mathrm{min}$. The influence of various factors, such as the sample weight, the furnace temperature, the carrier gas flow velocity on the test course and the analysis speed, was determined. Increased carrier gas flow of up to $70 \mathrm{ml} / \mathrm{min}$ does not shorten the analysis time. In some cases, an increase in the oven temperature may speed up the analysis, but this is quite risky for some samples that decompose at given temperature. It is therefore safer to conduct the test at an oven temperature
\end{abstract}

Autor do korespondencji: S. Jędrychowska, e-mail: sylwia.jedrychowska@inig.pl

Artykuł nadesłano do Redakcji: 03.02.2021 r. Zatwierdzono do druku: 08.07.2021 r. 
of $150^{\circ} \mathrm{C}$. The speed of analysis is most influenced by an appropriate selection of the sample quantity under analysis. Depending on the water content in the tested sample, the appropriate sample weight should be selected. It should be small enough not to excessively extend the analysis, but also large enough that the amount of titrated water is at least twice as large as in the blank.

Key words: water, Coulometric KF titration with evaporation, lubricating oils.

\section{Wstęp}

Literatura podaje wiele przykładów wpływu obecności wody na właściwości użytkowe różnych produktów i na korodowanie elementów, z którymi dany produkt ma kontakt. Dotyczy to przede wszystkim środków smarowych (Urzędowska i Stępień, 2012; Fatima et al., 2015; Soltanahmadi et al., 2017; Smoliło, 2020). Wnikanie wody, jako zanieczyszczenia, do środka smarnego, wpływa na jego działanie, prowadząc do zmian w zużyciu, do korozji i uszkodzenia smarowanych elementów, zwłaszcza w łożyskach tocznych. W olejach przekładniowych ATF (ang. automatic transmission fluid), stosowanych w pojazdach $z$ automatycznymi skrzyniami biegów, obecność wody osłabia działanie płynu ATF poprzez zwiększenie tarcia, może zmieniać nasiąkliwość dodatków powierzchniowo czynnych, co może powodować pogorszenie właściwości ciernych (Fatima et al., 2016).

Metoda miareczkowania kulometrycznego Karla Fischera (KF) z odparowaniem zalecana jest w przypadku próbek stałych i ciekłych, które uwalniają wodę tylko w wyższych temperaturach (powyżej $50^{\circ} \mathrm{C}$ ), reagują z odczynnikiem KF (reakcje uboczne) lub się w nim nie rozpuszczają. Metoda jest szeroko stosowana do pomiaru wilgoci w różnych produktach. Ma szereg zalet, do których należą przede wszystkim selektywność i dokładność metody oraz krótki czas analizy. Metodę bezpośredniego miareczkowania kulometrycznego KF zastosowali Dobry i Zmarzły (2010) do analizy zmian stanu zawilgocenia w nanomodyfikowanych, domieszkowanych fulerenami C60, próbkach olejów izolacyjnych z eksploatacji. Metodę kulometrycznego miareczkowania Karla Fischera z odparowaniem wykorzystuje się często do badania zawartości wody w produktach żywnościowych, trudnych do bezpośredniej analizy ze względu na specyfikę matrycy. Kestens et al. (2008) udowodnili, że metoda z odparowaniem bardzo dobrze się sprawdza w badaniu produktów spożywczych zawierających skrobię (m.in. mąka żytnia i pszenna, odtłuszczone mleko w proszku, chleb tostowy). Jest ona z powodzeniem używana i daje bardzo dobre wyniki. Natomiast Merkh z zespołem (2012) tę samą technikę zastosowali do oznaczania wody w wybranych produktach mleczarskich (w różnych typach masła, serów topionych i twardych serów) i porównali ją z metodą standardowo wykorzystywaną do takich produktów, czyli suszeniem ich w piecu i bezpośrednim miareczkowaniem Karla Fischera. Wykazali, że obie metody dają bardzo zbliżone wyniki, przy czym zaletą zautomatyzowanej metody z piecykiem jest oszczędność czasu przy oznaczaniu dużej liczby próbek. Lanz et al. (2006) i Merkh et al. (2012) przedstawili pracę nad optymalizacją techniki miareczkowania kulometrycznego Karla Fischera z celą bez diafragmy do stosowania w szerokim zakresie oznaczania wody w produktach żywnościowych charakteryzujących się niską zawartością wody, takich jak oleje jadalne. Dodatkowo porównali dwa układy celi miareczkowej bez diafragmy i z diafragmą, wykazując dobrą zgodność obu technik nawet dla niskich zawartości wody - poniżej $20 \mu \mathrm{g}$. Hinz (2007) ocenił pięć różnych metod oznaczania wody w produktach o nieznanych właściwościach chemicznych i termicznych. Na podstawie szczegółowych rozważań dotyczących selektywności, rodzaju wiązania wody, właściwości próbek i wydajności stwierdził, że połączenie bezpośredniego miareczkowania Karla Fischera i metody z piecem Karla Fischera jest optymalną techniką w przypadku takich substancji. Metodę piecykową stosowano także do analizy zawartości wilgoci w proszkach metali (Mellin et al., 2020), w próbkach 1-oktanolu nasyconego wodą, cementu, węgla i rafinowanego oleju (Margolis et al., 2004a), a także w filtrach cząstek stałych. W tym ostatnim przypadku metoda pozwoliła na ilościową ocenę różnych rodzajów wody (luźno związanej, absorpcyjnej i krystalicznej) (Canepari et al., 2013; Rogula-Kozłowska et al., 2017; Widziewicz-Rzońca et al., 2020). Margolis et al. (2004b) wykorzystali metodę z odparowaniem do badania olejów smarowych. W wyniku przeprowadzonych badań stwierdzili, że istnieje wiele źródeł podwyższających wyniki oznaczania zawartości wody i że standardowy odczynnik KF nie może być używany do badania olejów silnikowych i dodatków w nich stosowanych. Ponadto zasugerowali, że część materiału, który był lotny w $160^{\circ} \mathrm{C}$, a nie w $107^{\circ} \mathrm{C}$, mogła być wodą, fizycznie okludowaną, lub substancjami, które reagują z eterem monometylowym glikolu dietylenowego $\mathrm{z}$ wytworzeniem wody.

Wiele substancji uwalnia zawartą wilgoć powoli albo w podwyższonej temperaturze, inne nie rozpuszczają się wcale lub rozpuszczają się słabo w alkoholach, a zatem w odczynniku Karla Fischera. W takiej sytuacji nie można stosować klasycznej bezpośredniej metody miareczkowania Karla Fischera. Istnieją co prawda procedury radzenia sobie w takich przypadkach, ale często są skomplikowane, czasochłonne lub szkodliwe dla zdrowia. Istnieją także substancje, które reagują 
z odczynnikami Karla Fischera, uwalniając dodatkowe ilości wody, lub wiążą jod zamiast wody, co zakłóca wyniki. Dzięki zastosowaniu metody piecykowej, zwanej także metodą z odparowaniem lub podgrzewaniem, można zapobiec powyższym problemom.

Użycie piecyka pozwala na odparowanie wilgoci zawartej w próbce i przetransportowanie jej za pomocą suchego gazu nośnego do celi miareczkowej, gdzie zostaje odmiareczkowana za pomocą wygenerowanego na anodzie jodu bez bezpośredniego kontaktu próbki z odczynnikiem Karla Fischera. Odpowiednio odważoną w specjalnej fiolce próbkę, zamkniętą hermetycznie z użyciem septy i metalowej nakrętki, umieszcza się w automatycznym podajniku próbek. Następnie próbka opuszczana jest do komory pieca, gdzie następuje jej podgrzanie do określonej w metodzie temperatury. Podwójna igła przebija membranę septy i osuszony gaz nośny przenosi uwolnioną wodę do celi miareczkowej. Zasadę ekstrakcji termicznej ilustruje rysunek 1 .

\section{Ekstrakcja termiczna}

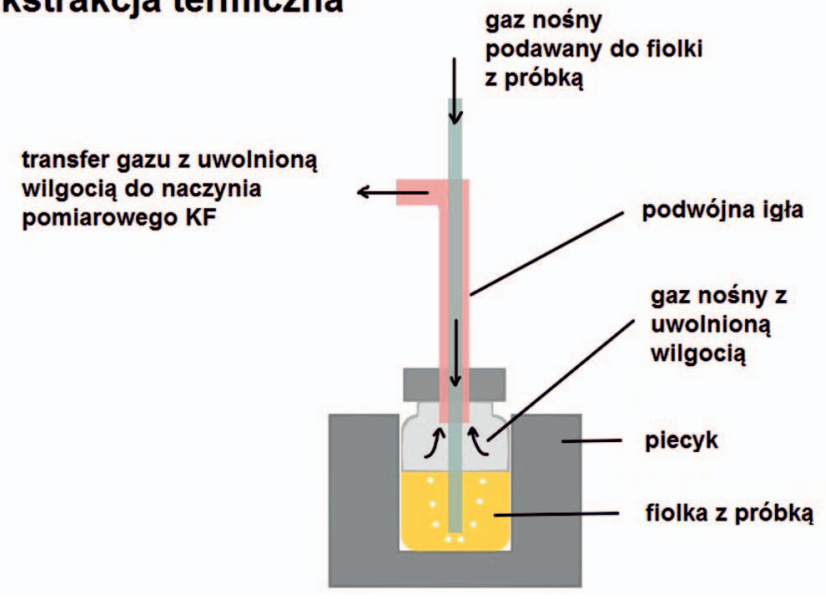

Rys. 1. Zasada ekstrakcji termicznej wody z próbki w piecyku (Metrohm Polska, 2016)

Fig. 1. Principle of thermal extraction of water from a sample in an oven (Metrohm Polska, 2016)

Zakres temperaturowy piecyka wynosi od $50^{\circ} \mathrm{C}$ do $250^{\circ} \mathrm{C}$, a przepływ gazu nośnego jest możliwy od $10 \mathrm{ml} / \mathrm{min}$ do $150 \mathrm{ml} / \mathrm{min}$. 18-pozycyjny podajnik pozwala na automatyczną analizę kilkunastu próbek w ustalonych warunkach serii.

\section{Aparatura i odczynniki}

Badania wykonano za pomocą kulometru firmy Metrohm model 917 Coulometer z celą miareczkową bez diafragmy, połączonego z automatycznym podajnikiem próbek wyposażonym w piecyk 885 Compact Oven Sample Changer. Parametry aparatury badawczej:
- $\quad$ prąd polaryzacji I (pol) $10 \mu \mathrm{A}$;

- prąd generacyjny $400 \mathrm{~mA}$.

Parametry kontrolne miareczkowania:

- punkt końcowy EP przy $50 \mathrm{mV}$;

- prędkość miareczkowania optymalna;

- min. szybkość $15 \mu \mathrm{g} / \mathrm{min}$;

- kryterium zatrzymania względny dryft;

- względny dryft stopu $5 \mu \mathrm{g} / \mathrm{min}$;

- czas ekstrakcji 300 s;

- przerwa czasowa $2 \mathrm{~s}$.

Parametry kondycjonowania:

- dryft $10 \mu \mathrm{g} / \mathrm{min}$;

- czas stabilizacji $60 \mathrm{~s}$.

Do badań wykorzystano odczynnik firmy Honeywell/Fluka Hydranal Coulomat AG-Oven, przeznaczony do metody miareczkowania kulometrycznego Karla Fischera z celą miareczkową z diafragmą i bez diafragmy oraz do pracy z próbkami ogrzewanymi w piecyku.

\section{Przebieg badań}

Przygotowanie aparatu do badań obejmowało następujące czynności:

- wysuszenie sit molekularnych $(0,3 \mathrm{~nm}) \mathrm{w}$ ciągu $24 \mathrm{~h}$ w temperaturze $300^{\circ} \mathrm{C}$;

- sprawdzenie czystości celi miareczkowej, elektrod generującej i pomiarowej;

- sprawdzenie szczelności wszystkich połączeń kulometru i przewodów gazu nośnego;

- sprawdzenie drożności igły wlotowej, przez którą wpływa osuszony gaz nośny do fiolki z próbką;

- sprawdzenie odczynnika Karla Fischera;

- kondycjonowanie kulometru;

- ustawienie odpowiedniej metody pracy kulometru i podajnika próbek wraz z piecykiem;

- wykonanie badania dwóch ślepych prób.

Po przeprowadzeniu wszystkich czynności opisanych powyżej można przystąpić do badania próbek.

Prawidłową pracę aparatu potwierdzono poprzez wykonanie badania zawartości wody w certyfikowanym materiale wzorcowym firmy Fluka o stężeniu nominalnym $5,11 \pm 0,02 \%(\mathrm{~m} / \mathrm{m})$. Na podstawie uzyskanych wyników obliczono odchylenie standardowe, względne odchylenie standardowe i współczynnik zmienności (uzyskane wyniki przedstawiono w tabeli 1).

Kryterium zgodności według producenta aparatu to otrzymanie współczynnika zmienności nie wyższego niż $2 \%$. Uzyskane wyniki spełniają powyższe kryterium i potwierdzają prawidłowe działanie aparatury. 
Tabela 1. Wyniki badania certyfikowanego materiału wzorcowego o nominalnej zawartości wody $5,10 \pm 0,02 \%(\mathrm{~m} / \mathrm{m})$

Table 1. Test results of a certified reference material with nominal water content of $5.10 \pm 0.02 \%(w / w)$

\begin{tabular}{|l|c|}
\hline \multicolumn{1}{|c|}{ Numer oznaczenia } & $\begin{array}{c}\text { Zawartość wody } \\
{[\mathbf{\%}(\mathbf{m} / \boldsymbol{m})]}\end{array}$ \\
\hline \hline Oznaczenie 1 & 5,1100 \\
\hline Oznaczenie 2 & 5,1011 \\
\hline Oznaczenie 3 & 5,0893 \\
\hline Oznaczenie 4 & 5,1001 \\
\hline Oznaczenie 5 & 5,1108 \\
\hline Oznaczenie 6 & 5,0935 \\
\hline Średnia [mg/kg] & 5,1008 \\
\hline Odchylenie standardowe [mg/kg] & 0,0086 \\
\hline Względne odchylenie standardowe & 0,001688 \\
\hline Współczynnik zmienności [\%] & 0,17 \\
\hline
\end{tabular}

\section{Badania olejów smarowych}

Do badań wytypowano następujące produkty naftowe:

- oleje silnikowe o klasach lepkości: 15W-40, 5W-40, 10W-40, 5W-30, próbka oleju silnikowego z badań międzylaboratoryjnych IIS 2020 r. o nieznanej klasie lepkości;

- olej turbinowy (próbka z badań międzylaboratoryjnych IIS 2020 r.);

- olej bazowy (próbka z badań międzylaboratoryjnych IIS 2020 r.);

- olej przekładniowy: mineralny olej przekładniowy Hipol GL-5 80W-90;

- olej hydrauliczny: mineralny olej hydrauliczny Castrol Aero 35 (Yellow);

- płyn hydrauliczny Hydrauny Coil FH42 (syntetyczny płyn do amortyzatorów).

Każda z wytypowanych próbek została zbadana pod kątem zawartości wody metodą miareczkowania kulometrycznego Karla Fischera w różnych warunkach pracy aparatu. Piecyk 885 Compact Oven Sample Changer umożliwia zmianę parametrów w zakresie temperatury grzania od $50^{\circ} \mathrm{C}$ do $250^{\circ} \mathrm{C}$ oraz szybkości przepływu gazu nośnego w zakresie od $10 \mathrm{ml} / \mathrm{min}$ do $150 \mathrm{ml} / \mathrm{min}$. Parametry pracy piecyka należy dobrać tak, aby w jak najkrótszym czasie cała woda obecna w próbce została przetransportowana do naczynia miareczkującego / celi miareczkowej. Wybrana temperatura piecyka powinna być jak najwyższa dla danej próbki, ponieważ im wyższa temperatura, tym krótszy czas analizy. Nie może jednak dojść do rozkładu termicznego próbki ani podczas termicznej ekstrakcji nie mogą uwalniać się inne składniki niż woda. Przepływ gazu powinien być utrzymany na jak najniższym poziomie, ale trzeba zachować czujność, aby nie dopuścić do kondensacji wody w rurkach transportowych. Przy doborze parametrów piecyka przede wszystkim trzeba wziąć pod uwagę rodzaj próbki, jej charakter chemiczny / matrycę i właściwości fizykochemiczne (Bruttel i Schlink, 2006).

Odpowiednią ilość próbki odważano bezpośrednio w szklanej fiolce o pojemności $8 \mathrm{ml}$ na wadze analitycznej z dokładnością $0,0001 \mathrm{~g}$. Po przeniesieniu próbki do fiolki jak najszybciej zakręcano szczelnie fiolkę za pomocą zakrętki z silikonową septą pokrytą od strony próbki PTFE. Następnie umieszczano fiolkę na stojaku podajnika i ustawiano odpowiedni program temperaturowy i przepływu gazu nośnego w aparacie. Po uruchomieniu aparatury fiolka z próbką automatycznie była opuszczana do nagrzanego piecyka. Następnie podwójna igła przebijała septę i strumień osuszonego za pomocą sit molekularnych powietrza był wprowadzany przez iglicę wlotową do fiolki. Przechodził przez ogrzaną próbkę i razem z uwolnioną parą wodną przedostawał się przez igłę wylotową oraz ogrzewaną rurkę transferową do celi miareczkowej, gdzie następowało oznaczenie zawartości wody metodą miareczkowania kulometrycznego Karla Fischera.

Dzięki temu, że do celi miareczkowej dostaje się tylko woda odparowana z próbki oraz że sama próbka nie wchodzi w kontakt z odczynnikiem Karla Fischera, teoretycznie wyklucza się występowanie reakcji ubocznych oraz efektów matrycy. Poza tym hermetyczne zamknięcie fiolki zapobiega zakłóceniom związanym z pobieraniem wilgoci z otoczenia, która dodatkowo uwzględniana jest poprzez wykonanie badań dwóch ślepych prób przed każdą serią oznaczeń. Po każdym oznaczeniu zawartości wody w próbce aparat automatycznie kondycjonuje się, czyli odmiareczkowuje ewentualną wilgoć całego układu, i dopiero po uzyskaniu odpowiednio niskiej wartości przystępuje do kolejnej analizy.

Ponieważ badano głównie produkty naftowe, charakteryzujące się wysokimi temperaturami wrzenia, zadecydowano, że badania przeprowadzone będą $\mathrm{w}$ zakresie temperatur pieca od $110^{\circ} \mathrm{C}$ do $180^{\circ} \mathrm{C}$ oraz przy trzech prędkościach przepływu gazu nośnego: $20 \mathrm{ml} / \mathrm{min}, 50 \mathrm{ml} / \mathrm{min}$ i $70 \mathrm{ml} / \mathrm{min}$. Każda próbka była analizowana dwukrotnie.

Wyniki badań próbek olejów smarowych przedstawiono w tabelach $2-5$. W celu porównania wyników dla różnych warunków uwalniania wody z próbki - dla każdej próbki obliczono rozstęp oraz procent wartości średniej, jaki ten rozstęp stanowi.

Na podstawie wyników zebranych w tabelach 2-5 można stwierdzić, że najniższą powtarzalność wyników uzyskano dla warunków temperatury grzania pieca $110^{\circ} \mathrm{C}$ i przepływu gazu nośnego $20 \mathrm{ml} / \mathrm{min}$. Temperatura w piecu na poziomie $180^{\circ} \mathrm{C}$ w wielu przypadkach (wyniki oznaczone *) okazała się za wysoka i doprowadziła do rozkładu termicznego próbki. Na rysunku 2 przedstawiono przykładową próbkę, która uległa rozkładowi. 
Tabela 2. Wyniki badań w warunkach ogrzewania pieca do $150^{\circ} \mathrm{C}$ i szybkości przepływu gazu nośnego $50 \mathrm{ml} / \mathrm{min}$

Table 2. Test results with furnace heating to $150^{\circ} \mathrm{C}$ and a carrier gas flow rate of $50 \mathrm{ml} / \mathrm{min}$

\begin{tabular}{|c|c|c|c|c|c|c|c|}
\hline Parametr & $\begin{array}{c}\text { Olej } \\
\text { silnikowy } \\
15 \mathrm{~W}-40\end{array}$ & $\begin{array}{c}\text { Olej } \\
\text { silnikowy } \\
5 \mathrm{~W}-40\end{array}$ & $\begin{array}{c}\text { Olej } \\
\text { silnikowy } \\
10 \mathrm{~W}-40\end{array}$ & $\begin{array}{c}\text { Olej } \\
\text { silnikowy } \\
5 \mathrm{~W}-30\end{array}$ & $\begin{array}{c}\text { Mineralny olej } \\
\text { przekladniowy } \\
\text { Hipol GL-5 } \\
80 W-90\end{array}$ & $\begin{array}{c}\text { Syntetyczny plyn } \\
\text { do amortyzatorów } \\
\text { Hydrauny Coil } \\
\text { FH42 }\end{array}$ & $\begin{array}{c}\text { Mineralny olej } \\
\text { hydrauliczny } \\
\text { Castrol Aero } 35 \\
\text { (Yellow) }\end{array}$ \\
\hline Oznaczenie $x_{1}[\mathrm{mg} / \mathrm{kg}]$ & 418 & 477 & 697 & 823 & 38 & 61 & 137 \\
\hline Oznaczenie $x_{2}[\mathrm{mg} / \mathrm{kg}]$ & 422 & 451 & 684 & 779 & 41 & 77 & 157 \\
\hline Średnia $x_{s r}[\mathrm{mg} / \mathrm{kg}]$ & 420 & 464 & 690,5 & 801 & 39,5 & 69 & 147 \\
\hline Rozstęp, $\Delta=x_{1}-\mathrm{x}_{2}[\mathrm{mg} / \mathrm{kg}]$ & 4 & 26 & 13 & 44 & 3 & 16 & 20 \\
\hline $\begin{array}{l}\text { Rozstęp } D, \text { jako \% średniej, } \\
D=\Delta \cdot 100 / x_{s r}\end{array}$ & 0,95 & 5,60 & 1,88 & 5,49 & 7,59 & 23,19 & 13,61 \\
\hline Średni rozstęp [\%] & \multicolumn{7}{|c|}{8,33} \\
\hline
\end{tabular}

Tabela 3. Wyniki badań w warunkach ogrzewania pieca do $180^{\circ} \mathrm{C}$ i szybkości przepływu gazu nośnego $50 \mathrm{ml} / \mathrm{min}$

Table 3. Test results with furnace heating to $180^{\circ} \mathrm{C}$ and a carrier gas flow rate of $50 \mathrm{ml} / \mathrm{min}$

\begin{tabular}{|c|c|c|c|c|c|c|c|}
\hline Parametr & $\begin{array}{c}\text { Olej } \\
\text { silnikowy } \\
15 W-40\end{array}$ & $\begin{array}{c}\text { Olej } \\
\text { silnikowy } \\
5 \mathrm{~W}-40\end{array}$ & $\begin{array}{c}\text { Olej } \\
\text { silnikowy } \\
10 \mathrm{~W}-40\end{array}$ & $\begin{array}{c}\text { Olej } \\
\text { silnikowy } \\
5 \mathrm{~W}-30\end{array}$ & $\begin{array}{c}\text { Mineralny olej } \\
\text { przekładniowy } \\
\text { Hipol GL-5 } \\
80 \text { W-90 } \\
\end{array}$ & $\begin{array}{c}\text { Syntetyczny płyn } \\
\text { do amortyzatorów } \\
\text { Hydrauny Coil } \\
\text { FH42 }\end{array}$ & $\begin{array}{c}\text { Mineralny olej } \\
\text { hydrauliczny } \\
\text { Castrol Aero } 35 \\
\text { (Yellow) } \\
\end{array}$ \\
\hline Oznaczenie $x_{1}[\mathrm{mg} / \mathrm{kg}]$ & 497 & 583 & $1042^{*}$ & 1030 & $1148^{*}$ & 84 & 204 \\
\hline Oznaczenie $x_{2}[\mathrm{mg} / \mathrm{kg}]$ & 458 & 605 & 861 & 1137 & $756^{*}$ & 89 & 200 \\
\hline Średnia $x_{s r}[\mathrm{mg} / \mathrm{kg}]$ & 477,5 & 594 & 951,5 & 1083,5 & 952 & 86,5 & 202 \\
\hline Rozstęp, $\Delta=x_{1}-x_{2}[\mathrm{mg} / \mathrm{kg}]$ & 39 & 22 & 181 & 107 & 392 & 5 & 4 \\
\hline $\begin{array}{l}\text { Rozstęp } D \text {, jako \% średniej, } \\
D=\Delta \cdot 100 / x_{s r}\end{array}$ & 8,17 & 3,70 & 19,02 & 9,88 & 41,18 & 5,78 & 1,98 \\
\hline Średni rozstęp [\%] & \multicolumn{7}{|c|}{12,81} \\
\hline
\end{tabular}

* Próbka uległa rozkładowi.

Tabela 4. Wyniki badań w warunkach ogrzewania pieca do $110^{\circ} \mathrm{C}$ i szybkości przepływu gazu nośnego $20 \mathrm{ml} / \mathrm{min}$

Table 4. Test results with furnace heating to $110^{\circ} \mathrm{C}$ and a carrier gas flow rate of $20 \mathrm{ml} / \mathrm{min}$

\begin{tabular}{|c|c|c|c|c|c|c|c|}
\hline Parametr & $\begin{array}{c}\text { Olej } \\
\text { silnikowy } \\
15 W-40\end{array}$ & $\begin{array}{c}\text { Olej } \\
\text { silnikowy } \\
5 \mathrm{~W}-40\end{array}$ & $\begin{array}{c}\text { Olej } \\
\text { silnikowy } \\
10 \mathrm{~W}-40\end{array}$ & $\begin{array}{c}\text { Olej } \\
\text { silnikowy } \\
5 \mathrm{~W}-30\end{array}$ & $\begin{array}{l}\text { Mineralny olej } \\
\text { przekładniowy } \\
\text { Hipol GL-5 } \\
80 W-90\end{array}$ & $\begin{array}{c}\text { Syntetyczny płyn } \\
\text { do amortyzatorów } \\
\text { Hydrauny Coil } \\
\text { FH42 }\end{array}$ & $\begin{array}{l}\text { Mineralny olej } \\
\text { hydrauliczny } \\
\text { Castrol Aero } 35 \\
\text { (Yellow) }\end{array}$ \\
\hline Oznaczenie $x_{1}[\mathrm{mg} / \mathrm{kg}]$ & 145 & 258 & 292 & 506 & 19 & 62 & 146 \\
\hline Oznaczenie $x_{2}[\mathrm{mg} / \mathrm{kg}]$ & 183 & 167 & 285 & 381 & 7 & 35 & 128 \\
\hline Średnia $x_{s r}[\mathrm{mg} / \mathrm{kg}]$ & 164 & 212,5 & 288,5 & 443,5 & 13 & 48,5 & 137 \\
\hline Rozstęp, $\Delta=x_{1}-x_{2}[\mathrm{mg} / \mathrm{kg}]$ & 38 & 91 & 7 & 125 & 12 & 27 & 18 \\
\hline $\begin{array}{l}\text { Rozstęp } D \text {, jako \% średniej, } \\
D=\Delta \cdot 100 / x_{s r}\end{array}$ & 23,17 & 42,82 & 2,43 & 28,18 & 92,31 & 55,67 & 13,14 \\
\hline Średni rozstęp [\%] & \multicolumn{7}{|c|}{36,82} \\
\hline
\end{tabular}

Tabela 5. Wyniki badań w warunkach ogrzewania pieca do $150^{\circ} \mathrm{C}$ i szybkości przepływu gazu nośnego $70 \mathrm{ml} / \mathrm{min}$

Table 5. Test results with furnace heating to $150^{\circ} \mathrm{C}$ and a carrier gas flow rate of $70 \mathrm{ml} / \mathrm{min}$

\begin{tabular}{|c|c|c|c|c|c|c|c|}
\hline Parametr & $\begin{array}{c}\text { Olej } \\
\text { silnikowy } \\
15 \mathrm{~W}-40\end{array}$ & $\begin{array}{c}\text { Olej } \\
\text { silnikowy } \\
5 \mathrm{~W}-40\end{array}$ & $\begin{array}{c}\text { Olej } \\
\text { silnikowy } \\
10 \mathrm{~W}-40\end{array}$ & $\begin{array}{c}\text { Olej } \\
\text { silnikowy } \\
5 \mathrm{~W}-30\end{array}$ & $\begin{array}{c}\text { Mineralny olej } \\
\text { przekladniowy } \\
\text { Hipol GL-5 } \\
80 W-90 \\
\end{array}$ & $\begin{array}{c}\text { Syntetyczny płyn } \\
\text { do amortyzatorów } \\
\text { Hydrauny Coil } \\
\text { FH42 } \\
\end{array}$ & $\begin{array}{c}\text { Mineralny olej } \\
\text { hydrauliczny } \\
\text { Castrol Aero } 35 \\
\text { (Yellow) } \\
\end{array}$ \\
\hline Oznaczenie $x_{1}[\mathrm{mg} / \mathrm{kg}]$ & 433 & 472 & 690 & 815 & 49 & 90 & 193 \\
\hline Oznaczenie $x_{2}[\mathrm{mg} / \mathrm{kg}]$ & 373 & 502 & 698 & 866 & 40 & 92 & 156 \\
\hline Średnia $x_{s r}[\mathrm{mg} / \mathrm{kg}]$ & 403 & 487 & 694 & 840,5 & 44,5 & 91 & 174,5 \\
\hline Rozstęp $\Delta=x_{1}-x_{2}[\mathrm{mg} / \mathrm{kg}]$ & 60 & 30 & 8 & 51 & 9 & 2 & 37 \\
\hline $\begin{array}{l}\text { Rozstęp } D, \text { jako \% średniej, } \\
D=\Delta \cdot 100 / x_{s r}\end{array}$ & 14,89 & 6,16 & 1,15 & 6,07 & 20,22 & 2,20 & 21,2 \\
\hline Średni rozstęp [\%] & \multicolumn{7}{|c|}{10,27} \\
\hline
\end{tabular}




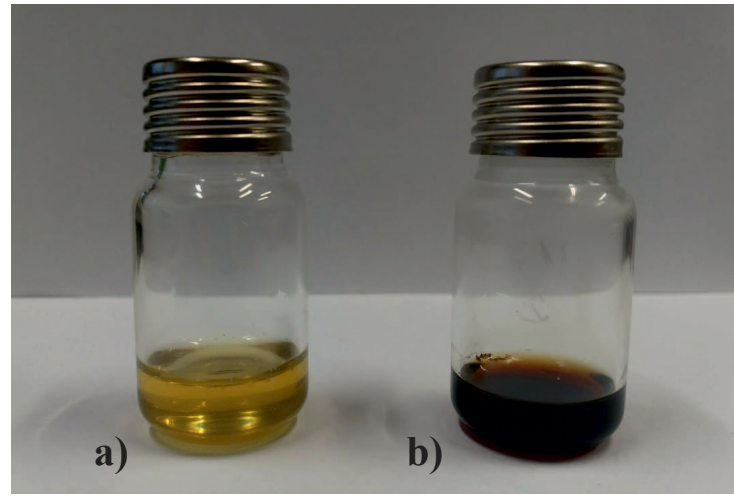

Rys. 2. Próbka oleju smarowego przed (a) i po analizie (b), w czasie której nastąpił jej rozkład

Fig. 2. Lubricating oil sample before (a) and after the analysis (b), during which it was decomposed
Oleje silnikowe z kolei wymagają wyższych temperatur do uwolnienia wody, ale pod warunkiem, że nie dojdzie do rozkładu próbki. Prawdopodobnie użycie azotu jako gazu nośnego mogłoby poprawić warunki badania i nie dopuścić do rozkładu. Generalnie najbardziej korzystne warunki to temperatura pieca $150^{\circ} \mathrm{C}$ i przepływ gazu nośnego na poziomie $50 \mathrm{ml} / \mathrm{min}$ lub $70 \mathrm{ml} / \mathrm{min}$.

\section{Wpływ masy badanej próbki na wyniki i czas analizy}

Jedną z zalet miareczkowania kulometrycznego Karla Fischera jest stosunkowo krótki czas analizy. Miareczkowanie bezpośrednie trwa $\mathrm{z}$ reguły kilka minut. Czas analizy ściśle związany jest z masą badanej próbki. Im większa naważka próbki, tym więcej wody zostanie wprowadzone do układu, a tym samym więcej jodu potrzeba na jej odmiareczkowanie. W związku z tym czas analizy będzie dłuższy. Dodatkową wadą zbyt dużych naważek jest szybsze zużywanie odczynnika Karla Fischera i konieczność jego wymiany. Zbyt niskie naważki próbki zawierają małe ilości wody, tak więc miareczkowanie obarczone jest dużym błędem. Wynik oznaczenia zbliżony do pozio-
Najmniejsze rozrzuty wyników uzyskano dla ustawień temperatury pieca $150^{\circ} \mathrm{C}$ i przepływu gazu nośnego na poziomie $50 \mathrm{ml} / \mathrm{min}$ oraz odpowiednio $150^{\circ} \mathrm{C}$ i $70 \mathrm{ml} / \mathrm{min}$. Dla większości próbek procentowa wartość rozrzutu wyniosła poniżej 10\%. W tabeli 6 zestawiono otrzymane wyniki badań dla tych samych próbek olejów smarowych w różnych warunkach badania.

Analiza wyników pomiarów zestawionych w tabeli 6 pokazuje, że dla wszystkich próbek najbardziej odstające są wyniki uzyskane w warunkach ogrzewania pieca do $110^{\circ} \mathrm{C}$ i przy przepływie gazu nośnego $20 \mathrm{ml} / \mathrm{min}$. Parametry te wydają się niewystarczające do efektywnego przeniesienia wilgoci do celi miareczkującej i w rezultacie wyniki są zaniżone.

Najmniejszy wpływ różnych warunków pomiaru zaobserwowano w przypadku oleju hydraulicznego. Olej przekładniowy w temperaturze $180^{\circ} \mathrm{C}$ uległ rozkładowi, co sugeruje, że wyższe temperatury ogrzewania nie są wskazane dla takich produktów. mu ślepej próby powoduje, że błąd pomiaru może wynosić nawet kilkadziesiąt procent. W takim wypadku należy zwiększyć masę badanej próbki, co nie zawsze jest możliwe ze względu na ograniczenie pojemności fiolki próbki (około $8 \mathrm{ml}$ ) umieszczanej w piecu. W związku z powyższym masę badanej próbki należy dopasować tak, aby ilość odmiareczkowanej wody była na tyle duża, żeby wpływ wilgoci pochodzącej z powietrza nie był znaczący, ale też na tyle mała, żeby nadmiernie nie wydłużać czasu analizy. Sam proces ogrzewania, odparowania próbki w piecyku i transportu pary wodnej do celi miareczkowej wydłuża czas analizy.

Na przykładzie dwóch próbek sprawdzono wpływ masy badanej próbki na uzyskane wyniki z wykorzystaniem analizy statystycznej (tab. 7 i 8). W tym celu każdą próbkę analizowano pięciokrotnie. Otrzymane wartości współczynników zmienności dla obu próbek są mniejsze niż $10 \%$ - wyniosły $5,2 \%$ i $6,0 \%$, zatem zmienność cechy nie jest istotna statystycznie. Masa próbki nie miała zatem wpływu na otrzymane wyniki badań. 
Tabela 7. Wyniki badania wpływu masy próbki na wynik oznaczenia dla oleju hydraulicznego

Table 7. Results of testing the influence of sample weight on the determination result for the hydraulic oil

\begin{tabular}{|c|c|c|c|}
\hline \multirow{2}{*}{ Próbka } & \multirow{2}{*}{$\begin{array}{c}\text { Numer } \\
\text { oznaczenia }\end{array}$} & Masa próbki & Wynik oznaczenia \\
\hline & & [g] & {$[\mathrm{mg} / \mathrm{kg}]$} \\
\hline \multirow{9}{*}{$\begin{array}{c}\text { Olej hydrauliczny } \\
\text { Castrol Aero } 35 \\
\text { (Yellow) }\end{array}$} & oznaczenie 1 & 0,3782 & 218 \\
\hline & oznaczenie 2 & 0,7747 & 217 \\
\hline & oznaczenie 3 & 1,3418 & 203 \\
\hline & oznaczenie 4 & 2,4900 & 194 \\
\hline & oznaczenie 5 & 4,1066 & 200 \\
\hline & \multicolumn{2}{|c|}{ średnia wyników $[\mathrm{mg} / \mathrm{kg}]$} & 206 \\
\hline & \multicolumn{2}{|c|}{ odchylenie standardowe $[\mathrm{mg} / \mathrm{kg}]$} & 10,6442 \\
\hline & \multicolumn{2}{|c|}{ względne odchylenie standardowe RSD } & 0,0515 \\
\hline & \multicolumn{2}{|c|}{ współczynnik zmienności CV [\%] } & 5,1571 \\
\hline
\end{tabular}

Tabela 8. Wyniki badania wpływu masy próbki na wynik oznaczenia dla oleju silnikowego

Table 8. Results of testing the influence of the sample weight on the determination result for the engine oil

\begin{tabular}{|c|c|c|c|}
\hline \multirow{4}{*}{ Próbka } & \multirow{2}{*}{$\begin{array}{c}\text { Numer } \\
\text { oznaczenia }\end{array}$} & Masa próbki & Wynik oznaczenia \\
\cline { 2 - 4 } & & {$[\mathbf{g}]$} & {$[\mathbf{m g} / \mathbf{k g}]$} \\
\hline \hline \multirow{4}{*}{$\begin{array}{c}\text { Olej silnikowy } \\
\text { 10W-30 }\end{array}$} & oznaczenie 1 & 0,4314 & 224 \\
\cline { 2 - 4 } & oznaczenie 2 & 0,7284 & 204 \\
\cline { 2 - 4 } & oznaczenie 3 & 1,1438 & 218 \\
\cline { 2 - 4 } & oznaczenie 4 & 2,2480 & 216 \\
\cline { 2 - 4 } & oznaczenie 5 & 3,1455 & 240 \\
\cline { 2 - 4 } & \multicolumn{2}{|c|}{ średnia wyników [mg/kg] } & 220 \\
\cline { 2 - 4 } & odchylenie standardowe [mg/kg] & 13,1453 \\
\cline { 2 - 4 } & względne odchylenie standardowe RSD & 0,0596 \\
\cline { 2 - 4 } & \multicolumn{2}{|c|}{ współczynnik zmienności CV [\%] } & 5,9643 \\
\hline
\end{tabular}

Na podstawie analiz przedmiotowych próbek zbadano wpływ ich masy na czas oznaczenia. Obliczono procentowe przyrosty masy dla każdego kolejnego oznaczenia oraz procentowe wydłużenie czasu analizy w stosunku do poprzedniego oznaczenia. Wyniki przedstawiono w tabeli 9. W przypadku naważek mniejszych od $1 \mathrm{~g}$ wzrost masy nawet o $100 \%$ nie powoduje znaczącego wydłużenia czasu analizy. Dla naważek powyżej 1,5 g wzrost masy powoduje zauważalne wydłużenie tego czasu, często w przybliżeniu o taką samą wartość procentową jak przyrost masy.

\section{Wpływ przepływu gazu na czas analizy}

Na podstawie badań wszystkich próbek określono wpływ szybkości przepływu gazu nośnego na czas analizy. W tym celu przedmiotowe próbki ogrzewano w piecyku w identycznej temperaturze $\left(150^{\circ} \mathrm{C}\right)$ oraz przy różnych prędkościach przepływu gazu nośnego. Dokładnie tej samej porcji próbki nie można badać dwa razy, ponieważ po ogrzaniu i odparowaniu próbka nie zawiera już wody. W celu porównania poszczególnych oznaczeń obliczono współczynnik, będący ilorazem czasu analizy i masy próbki. Stwierdzono, że im niższą wartość osiągnie współczynnik, tym czas analizy jest krótszy. Wyniki przedstawiono w tabeli 10.

$\mathrm{Na}$ podstawie dokonanych obliczeń nie stwierdzono znaczących różnic w czasie analizy.

Tabela 9. Wyniki badania wpływu masy próbki na czas oznaczenia na przykładzie oleju silnikowego i oleju hydraulicznego

Table 9. Results of testing the influence of the sample weight on the determination time on the example of engine oil and hydraulic oil

\begin{tabular}{|c|c|c|c|c|c|}
\hline \multirow[t]{2}{*}{ Próbka } & \multirow[t]{2}{*}{ Numer oznaczenia } & Masa próbki & Czas oznaczenia & $\begin{array}{l}\text { Przyrost masy - } \\
\text { o ile procent }\end{array}$ & $\begin{array}{c}\text { Wydłużenie czasu } \\
\text { oznaczenia - o ile procent }\end{array}$ \\
\hline & & {$[g]$} & [minuty] & {$[\%]$} & {$[\%]$} \\
\hline \multirow{5}{*}{$\begin{array}{c}\text { Olej hydrauliczny } \\
\text { Castrol Aero } 35 \text { (Yellow) }\end{array}$} & oznaczenie 1 & 0,3782 & 5,0 & - & - \\
\hline & oznaczenie 2 & 0,7747 & 5,0 & 104,84 & 0,07 \\
\hline & oznaczenie 3 & 1,3418 & 5,5 & 73,20 & 9,38 \\
\hline & oznaczenie 4 & 2,49 & 10,0 & 85,57 & 80,98 \\
\hline & oznaczenie 5 & 4,1066 & 15,7 & 64,92 & 57,59 \\
\hline \multirow{5}{*}{$\begin{array}{l}\text { Olej silnikowy } \\
\text { 10W-30 }\end{array}$} & oznaczenie 1 & 0,4314 & 8,9 & - & - \\
\hline & oznaczenie 2 & 0,7284 & 11,1 & 68,85 & 24,94 \\
\hline & oznaczenie 3 & 1,1438 & 19,1 & 57,03 & 71,51 \\
\hline & oznaczenie 4 & 2,2480 & 36,8 & 96,54 & 93,15 \\
\hline & oznaczenie 5 & 3,1455 & 56,0 & 39,92 & 52,13 \\
\hline
\end{tabular}


Tabela 10. Wyniki obliczeń określających wpływ szybkości przepływu gazu nośnego na czas analizy

Table 10. Calculation results determining the influence of the carrier gas flow rate on the analysis time

\begin{tabular}{|c|c|c|c|c|c|c|}
\hline Warunki badania & \multicolumn{3}{|c|}{$150^{\circ} \mathrm{C}, 50 \mathrm{ml} / \mathrm{min}$} & \multicolumn{3}{|c|}{$150^{\circ} \mathrm{C}, 70 \mathrm{ml} / \mathrm{min}$} \\
\hline \multirow{2}{*}{ Rodzaj próbki } & masa $m$ & czas analizy $t$ & współczynnik $t / m$ & masa $m$ & czas analizy $t$ & współczynnik $t / m$ \\
\hline & [g] & [minuty] & [minuty/g] & {$[g]$} & [minuty] & [minuty/g] \\
\hline Olej silnikowy IIS ${ }^{*}$ & 1,9734 & 23,6 & 11,94 & 2,2994 & 39,1 & 17,00 \\
\hline Olej silnikowy IIS* & 1,7341 & 20,4 & 11,77 & 0,9622 & 8,8 & 9,12 \\
\hline Olej silnikowy $15 \mathrm{~W}-40$ & 2,8893 & 43,3 & 14,99 & 2,0695 & 37,5 & 18,11 \\
\hline Olej silnikowy $15 \mathrm{~W}-40$ & 2,0684 & 30,3 & 14,64 & 2,7174 & 32,6 & 12,01 \\
\hline Olej silnikowy 5W-40 & 2,1284 & 33,9 & 15,94 & 2,0864 & 39,4 & 18,90 \\
\hline Olej silnikowy $5 \mathrm{~W}-40$ & 3,3046 & 50,9 & 15,40 & 2,0891 & 42,1 & 20,16 \\
\hline Olej silnikowy $10 \mathrm{~W}-40$ & 3,5012 & 69,4 & 19,82 & 1,8943 & 42,9 & 22,64 \\
\hline Olej silnikowy $10 \mathrm{~W}-40$ & 2,1166 & 40,0 & 18,92 & 2,3902 & 53,6 & 22,45 \\
\hline Olej silnikowy 5W-30 & 4,2118 & 89,5 & 21,25 & 2,2634 & 57,8 & 25,52 \\
\hline Olej silnikowy $5 \mathrm{~W}-30$ & 1,5217 & 32,5 & 21,39 & 2,3414 & 63,3 & 27,04 \\
\hline $\begin{array}{l}\text { Olej przekładniowy } \\
\text { Hipol GL-5 80W-90 }\end{array}$ & 3,2635 & 5,0 & 1,55 & 1,3993 & 5,0 & 3,60 \\
\hline $\begin{array}{l}\text { Olej przekładniowy } \\
\text { Hipol GL-5 80W-90 }\end{array}$ & 2,8157 & 5,0 & 1,79 & 3,1653 & 5,5 & 1,73 \\
\hline Płyn hydrauliczny & 2,3954 & 7,6 & 3,17 & 1,7578 & 8,2 & 4,67 \\
\hline Płyn hydrauliczny & 2,816 & 11,0 & 3,90 & 2,9722 & 10,0 & 3,36 \\
\hline Olej hydrauliczny & 1,778 & 6,5 & 3,64 & 2,8119 & 10,5 & 3,75 \\
\hline Olej hydrauliczny & 3,3177 & 13,1 & 3,96 & 2,0827 & 6,0 & 2,86 \\
\hline Olej turbinowy & 0,8082 & 5,0 & 6,23 & 1,9821 & 5,0 & 2,54 \\
\hline Olej turbinowy & 2,4641 & 5,0 & 2,04 & 2,2119 & 5,0 & 2,28 \\
\hline Olej bazowy & 2,4986 & 5,0 & 2,02 & 2,5957 & 5,0 & 1,94 \\
\hline Olej bazowy & 4,6687 & 5,0 & 1,08 & 2,4853 & 5,0 & 2,03 \\
\hline Średni współczynnik $t / m$ [min/g] & & 10,2 & & & 11,6 & \\
\hline
\end{tabular}

* IIS - próbka pochodzi z międzynarodowych badań międzylaboratoryjnych organizowanych przez IIS.

Teoretycznie większa prędkość przepływu gazu nośnego powinna skutkować szybszym uwolnieniem wody z próbki i przetransportowaniem jej do celi miareczkowej. Wyniki doświadczalne nie potwierdzają jednak tej tezy. Wręcz przeciwnie - średnia współczynnika obliczonego dla przepływu $50 \mathrm{ml} / \mathrm{min}$ jest minimalnie mniejsza niż dla przepływu $70 \mathrm{ml} / \mathrm{min}$. Kolorem szarym w tablicy 10 zaznaczono niższą wartość współczynnika dla danego produktu. W przypadku olejów smarowych występują bardzo niewielkie różnice, zatem w praktyce można stosować obie prędkości przepływu gazu nośnego.

\section{Wpływ temperatury pieca na czas analizy}

Na podstawie badań wszystkich próbek określono wpływ temperatury grzania piecyka na czas analizy. W tym celu takie same próbki ogrzewano w piecyku w dwóch różnych temperaturach: $150^{\circ} \mathrm{C}$ i $180^{\circ} \mathrm{C}$ przy takiej samej prędkości przepływu gazu nośnego, wynoszącej $50 \mathrm{ml} / \mathrm{min}$. Dla porównania poszczególnych oznaczeń obliczono współczynnik będący ilorazem czasu analizy i masy próbki. Im niższą wartość osiągnie współczynnik, tym czas analizy jest krótszy. Wyniki obliczeń przedstawiono w tabeli 11.

Na podstawie doświadczeń i dokonanych obliczeń można stwierdzić, że po odrzuceniu wyników próbek, które w trakcie analizy uległy rozkładowi lub dla których nie osiągnięto punktu równoważnikowego, średni współczynnik $t / m$ dla warunków w temperaturze $150^{\circ} \mathrm{C}$ jest niższy niż w $180^{\circ} \mathrm{C}$. Zatem korzystniej jest stosować temperaturę grzania pieca do wysokości $150^{\circ} \mathrm{C}$. Kolorem szarym zaznaczono w tabeli 11 niższą wartość współczynnika dla danego produktu. Jedynie w przypadku oleju turbinowego zaobserwowano skrócenie czasu analizy pod wpływem wyższej temperatury pieca - oraz minimalne w przypadku płynu hydraulicznego. Generalnie można stwierdzić, że wzrost temperatury ogrzewania pieca ze $150^{\circ} \mathrm{C}$ do $180^{\circ} \mathrm{C}$ nie powoduje skrócenia czasu analizy dla badanych produktów. 
Tabela 11. Wyniki obliczeń określających wpływ temperatury grzania piecyka na czas analizy

Table 11. Calculation results determining the influence of the oven's heating temperature on the analysis time

\begin{tabular}{|c|c|c|c|c|c|c|}
\hline Warunki badania & \multicolumn{3}{|c|}{$150^{\circ} \mathrm{C}, 50 \mathrm{ml} / \mathrm{min}$} & \multicolumn{3}{|c|}{$180^{\circ} \mathrm{C}, 50 \mathrm{ml} / \mathrm{min}$} \\
\hline \multirow{2}{*}{ Rodzaj próbki } & masa $m$ & czas analizy $t$ & współczynnik $t / m$ & masa $m$ & czas analizy $t$ & współczynnik $t / m$ \\
\hline & {$[g]$} & [minuty] & [minuty/g] & {$[g]$} & [minuty] & [minuty/g] \\
\hline Olej silnikowy IIS ${ }^{* *}$ & 1,9734 & 23,6 & 11,94 & 1,5457 & 25,4 & 16,40 \\
\hline Olej silnikowy IIS S $^{* *}$ & 1,7341 & 20,4 & 11,77 & 1,6495 & 33,5 & 20,29 \\
\hline Olej silnikowy $15 \mathrm{~W}-40$ & 2,8893 & 43,3 & 14,99 & 2,5561 & 46,3 & 18,11 \\
\hline Olej silnikowy $15 \mathrm{~W}-40$ & 2,0684 & 30,3 & 14,64 & 1,564 & 25,3 & 16,18 \\
\hline Olej silnikowy 5W-40 & 2,1284 & 33,9 & 15,94 & 1,3146 & 23,8 & 18,10 \\
\hline Olej silnikowy $5 \mathrm{~W}-40$ & 3,3046 & 50,9 & 15,40 & 1,5639 & 30,5 & 19,47 \\
\hline Olej silnikowy $10 \mathrm{~W}-40$ & 3,5012 & 69,4 & 19,82 & 2,613 & 118,2 & $45,24^{*}$ \\
\hline Olej silnikowy 10W-40 & 2,1166 & 40,0 & 18,92 & 2,1469 & 50,5 & $23,54^{*}$ \\
\hline Olej silnikowy $5 \mathrm{~W}-30$ & 4,2118 & 89,5 & 21,25 & 2,4125 & 68,9 & 28,55 \\
\hline Olej silnikowy 5W-30 & 1,5217 & 32,5 & 21,39 & 1,9878 & 71,3 & 35,89 \\
\hline $\begin{array}{l}\text { Olej przekładniowy } \\
\text { Hipol GL-5 80W-90 }\end{array}$ & 3,2635 & 5,0 & 1,55 & 3,1239 & 461,6 & $147,77^{*}$ \\
\hline $\begin{array}{l}\text { Olej przekładniowy } \\
\text { Hipol GL-5 80W-90 }\end{array}$ & 2,8157 & 5,0 & 1,79 & 3,4534 & 241,2 & $69,84^{*}$ \\
\hline Płyn hydrauliczny & 2,3954 & 7,6 & 3,17 & 2,5581 & 7,4 & 2,91 \\
\hline Płyn hydrauliczny & 2,816 & 11,0 & 3,90 & 3,5352 & 9,9 & 2,81 \\
\hline Olej hydrauliczny & 1,778 & 6,5 & 3,64 & 3,0298 & 19,6 & 6,46 \\
\hline Olej hydrauliczny & 3,3177 & 13,1 & 3,96 & 3,8664 & 24,5 & 6,34 \\
\hline Olej turbinowy & 0,8082 & 5,0 & 6,23 & 3,2805 & 5,0 & 1,53 \\
\hline Olej turbinowy & 2,4641 & 5,0 & 2,04 & 3,5365 & 5,0 & 1,43 \\
\hline Olej bazowy & 2,4986 & 5,0 & 2,02 & 3,6461 & 148,3 & $40,67^{*}$ \\
\hline Olej bazowy & 4,6687 & 5,0 & 1,08 & 1,1589 & 73,9 & $63,72 *$ \\
\hline Średni współczynnik $t / m$ [min/g] & & 10,2 & & & 13,9 & \\
\hline
\end{tabular}

*Z obliczeń wyłączono wyniki oznaczone gwiazdką ze względu na rozkład próbki lub bardzo długi czas analizy, którą przerywano bez osiągnięcia punktu końcowego.

** IIS - próbka pochodzi z międzynarodowych badań międzylaboratoryjnych organizowanych przez IIS.

\section{Wyniki i wnioski}

Przeprowadzone badania miały na celu dobranie optymalnych warunków oznaczania zawartości wody metodą miareczkowania Karla Fischera z odparowaniem próbki dla olejów smarowych. Wykonano badania w czterech różnych warunkach pomiarowych: $110^{\circ} \mathrm{C}$ i $20 \mathrm{ml} / \mathrm{min} ; 150^{\circ} \mathrm{C}$ i $50 \mathrm{ml} / \mathrm{min}$; $180^{\circ} \mathrm{C}$ i $50 \mathrm{ml} / \mathrm{min}$ oraz $150^{\circ} \mathrm{C}$ i $70 \mathrm{ml} / \mathrm{min}$. Stwierdzono, że najlepsze wyniki uzyskano w temperaturze pieca $150^{\circ} \mathrm{C}$ i przy przepływie gazu nośnego $50 \mathrm{ml} / \mathrm{min}$ lub $70 \mathrm{ml} / \mathrm{min}$.

Zwiększony przepływ gazu nośnego do $70 \mathrm{ml} / \mathrm{min}$ nie powoduje skrócenia czasu analizy. W niektórych przypadkach wzrost temperatury pieca może przyspieszyć szybkość analizy, ale jest to dość ryzykowne, ponieważ część próbek w tej temperaturze ulega rozkładowi. W związku z tym bezpieczniej jest prowadzić badanie w temperaturze pieca $150^{\circ} \mathrm{C}$.
Największy wpływ na szybkość analizy ma odpowiedni dobór naważki próbki poddanej analizie. W zależności od zawartości wody w badanej próbce należy dobrać odpowiednią naważkę próbki. Powinna być na tyle mała, aby nadmiernie nie wydłużać analizy, ale także na tyle duża, żeby ilość odmiareczkowanej wody była przynajmniej dwukrotnie większa niż w ślepej próbie.

Artykuł powstał na podstawie pracy badawczej pt. Optymalizacja warunków oznaczania wody metoda kulometryczna z odparowaniem dla różnych produktów - praca INiG - PIB na zlecenie MNiSW; nr zlecenia: 0042/TA/2020, nr archiwalny: DK-4100-0030/2020.

\section{Literatura}

Bruttel P., Schlink R., 2006. Water Determination by Karl Fischer Titration. Monografia Metrohm. 
Canepari S., Farao C., Marconi E., Giovannelli C., Perrino C., 2013. Qualitative and quantitative determination of water in airborne particulate matter. Atmos. Chem. Phys., 13(3): 1193-1202. DOI: 10.5194/acp-13-1193-2013.

Dobry D., Zmarzły D., 2010. Pomiar i analiza zawilgocenia nanomodyfikowanych olejów izolacyjnych metodą bezpośredniego miareczkowania kulometrycznego Karla Fischera. Pomiary Automatyka Robotyka, 12: 124-126.

Fatima N., Minami I., Holmgren A., Marklund P., Berglund K., Larsson R., 2015. Influence of water on the tribological properties of zinc dialkyl-dithiophosphate and over-based calcium sulphonate additives in wet clutch contacts. Tribol. Int., 87: 113-120. DOI: 10.1016/j.triboint.2015.02.006.

Fatima N., Minami I., Holmgren A., Marklund P., Larsson R., 2016. Surface chemistry of wet clutch influenced by water contamination in automatic transmission fluids. Tribol. Int., 96: 395-401. DOI: 10.1016/j.triboint.2015.04.010.

Hinz D.C., 2007. Evaluation of methods for the determination of water in substances with unknown chemical and thermal behaviour. J. Pharm. Biomed. Anal. 43(2): 779-783. DOI: 10.1016/j. jpba.2006.08.002.

Kestens V., Conneely P., Bernreuther A., 2008. Vaporisation coulometric Karl Fischer titration: A perfect tool for water content determination of difficult matrix reference materials. Food Chem. 106(4): 1454-1459. DOI: 10.1016/j.foodchem.2007.01.079.

Lanz M., De Caro C.A., Rüegg K., De Agostini A., 2006. Coulometric Karl Fischer titration with a diaphragm-free cell: Cell design and applications. Food Chemistry, 96(3): 431-435. DOI: 10.1016/j. foodchem.2005.03.050

Margolis S.A., Vaishnav K., Sieber J.R., 2004a. Measurement of water by oven evaporation using a novel oven design. 1. Water in watersaturated 1-octanol, coal, cement, and refined oils. Anal. Bioanal. Chem. 380(3): 556-562. DOI: 10.1007/s00216-004-2778-8.

Margolis S.A., Vaishnav K., Sieber J.R., 2004b. Measurement of water by oven evaporation using a novel oven design. 2 . Water in motor oils and motor oil additives. Anal. Bioanal. Chem. 380(5-6): 843-52. DOI: 10.1007/s00216-004-2829-1.

Mellin P., Zavalis T., Tingö L., Brodin H., Wendel J., Berg S., Riabov D., Strondl A., Nyborg L., 2020. Moisture content analysis of metal powders, using oven desorption followed by Karl Fischer titration. Euro PM 2018. Congress and Exhibition. European Powder Metallurgy Association (EPMA).

Merkh G., Pfaff R., Isengard H.D., 2012. Capabilities of automated Karl Fischer titration combined with gas extraction for water determination in selected dairy products. Food Chemistry, 132(4), 1736-1740. DOI: 10.1016/j.foodchem.2011.11.001.

Metrohm Polska, 2016. Materiaty seminarium Karl Fischer Tour. Kraków, 2.02.2016.

Rogula-Kozłowska W., Widziewicz K., Majewski G., 2017. A simple method for determination of total water in $\mathrm{PM}_{1}$ on quartz fiber filters. Microchemical Journal, 132: 327-332. DOI: 10.1016/j. microc.2017.02.019.

Smoliło M., 2020. Badanie odporności na utlenianie mieszanin olejów otrzymanych z regeneracji olejów przepracowanych z olejami naftenowymi. Nafta-Gaz, 6: 408-418. DOI: 10.18668/ NG.2020.06.06.

Soltanahmadi S., Morina A., van Eijk M.C.P., Nedelcu I., Neville A., 2017. Tribochemical study of micropitting in tribocorrosive lubricated contacts: The influence of water and relative humidity. Tribol. Int. 107: 184-198. DOI: 10.1016/j.triboint.2016.11.031.

Urzędowska W., Stępień Z., 2012. Oddziaływanie paliwa na zmiany właściwości użytkowych oleju smarowego w silniku z ZI typu FlexFuel. Nafta-Gaz, 6: 377-387.

Widziewicz-Rzońca K., Tytła M., Majewski G., Rogula-Kopiec P., Loska K., Rogula-Kozłowska W., 2020. Strongly and loosely bound water in ambient particulate matter-Qualitative and quantitative determination by Karl Fischer Coulometric Method. Sustainability, 12(15): 6196. DOI: 10.3390/su12156196.

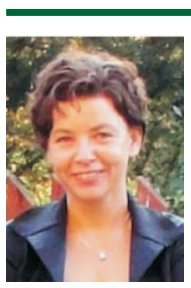

Mgr Sylwia JĘDRYCHOWSKA

Specjalista badawczo-techniczny w Zakładzie Analiz Naftowych

Instytut Nafty i Gazu - Państwowy Instytut Badawczy ul. Lubicz $25 \mathrm{~A}$

31-503 Kraków

E-mail: sylwia.jedrychowska@inig.pl 